\title{
Variation of vessel lumen diameter in radial direction as an indication of the juvenile wood growth in oak (Quercus petraea Liebl)
}

\author{
L Helińska-Raczkowska \\ Department of Wood Science, Agricultural University, ul Wojska Polskiego, 38-42, \\ 60-627 Poznan; Poland
}

(Received 29 October 1992; accepted 8 January 1994)

\begin{abstract}
Summary - Radial variations of vessel lumen diameters and number of vessels per unit area were investigated in sessile oak wood from 3 trees in the same stand. With increasing growth-ring age, the lumen diameters of earlywood and latewood vessels and the number of earlywood vessels per unit area increased, especially in the core zone of stem cross-section; the number of earlywood vessels per unit area decreased. Results of measurements of the variation in conductive elements in oak wood suggest that the juvenile (core) wood of the oak trees may contain approximately 30 growth rings. For the same annual rings from the pith, a very significant tree effect appeared for the vessel characteristics measured.
\end{abstract}

\section{Quercus petraea / vessel / diameter / number per unit area}

Résumé - La variation radiale du diamètre du lumen des vaisseaux du bois, un indice de la durée de la période de croissance juvénile chez le chêne (Quercus petraea Liebl). On a examiné l'évolution du diamètre des lumens des vaisseaux et de leur nombre par unité de surface depuis la moelle jusqu'à l'écorce sur 3 chênes sessiles provenant d'un même peuplement. Lorsque l'âge du cerne compté depuis la moelle augmente, le diamètre des lumens des vaisseaux du bois de printemps augmente et leur nombre par unité de surface diminue. Dans le bois d'été, le diamètre des lumens et leur nombre par unité de surface augmente lorsque l'âge augmente. Cet effet de l'âge du cerne est très sensible au voisinage de la moelle. Les résultats de l'étude des variations des éléments conducteurs en fonction de l'âge depuis la moelle montrent que la zone de bois juvénile chez le chêne concerne à peu près les 30 premiers cernes depuis la moelle. Pour le même âge depuis la moelle, un effet individuel (effet arbre) très significatif apparait pour les caractéristiques des vaisseaux prises en considération dans l'étude.

\section{Quercus petraea / vaisseaux / diamètre / nombre par unité de surface}




\section{INTRODUCTION}

This paper is a continuation of studies on the variation in the structures and properties of oak wood (Maeglin, 1976; Petric and Šćukanec, 1980; Nepveu, 1984a, 1984b, 1990; Gasson, 1985; Helińska-Raczkowska, 1990; Helińska-Raczkowska and Fabisiak, 1991). An improved understanding of the laws governing changes in structural features of wood in the function of wood crosssection radii, as well as the relationship between these changes and conditions of tree growth in a stand, is very important from the wood-application and silviculturepractice points of view. It should be noted that only quantitative assessments of the influence of different factors on wood formation will provide the information needed in silviculture practice so as to produce trees of a desired quality (Trotter, 1986; Wagenführ et al, 1989). In previous studies, juvenile wood produced by juvenile (immature) cambium was investigated, but little attention has been paid to the hardwoods (Nepveu, 1981; Zobel and van Buijtenen, 1989). In particular, a lack of reliable criteria for distinguishing the juvenile and mature wood in one tree appears to be very inconvenient. Therefore, in this study lumen diameters of earlywood and latewood vessels and the number of vessels per unit area in oak trees of even-aged stands with different growth characteristics were measured to fill the information gap.

\section{MATERIALS AND METHODS}

The experimental site was located in a 78 -year-old (according to the management plan) even-aged oak stand (Quercus petraea Liebl) in the western part of Poland $\left(52^{\circ} 33^{\prime} \mathrm{N}\right.$ and $16^{\circ} 50^{\prime} \mathrm{E}$ ) on the site of the experimental forests of the Agricultural University in Poznani. With reference to the measured diameters of trees, one experimental tree was selected from each of the dominant, intermediate, and suppressed classes (table I). Discs for experiments were taken at a height corresponding to the $1 / 4$ height of the tree measured from the butt-end (table II). Strips were cut along the northern radius of each disc $(20 \mathrm{~mm}$ in width along the tangential direction and $20 \mathrm{~mm}$ in height along the fibres). For the investigation, the following annual rings, counted from the pith, were selected: $3,6,9,12,15$, and further out towards the bark, every fifth ring. Permanent slides of growth-ring transection were taken from each of these rings for measurements.

The lumen diameter of earlywood and latewood vessels was measured on samples to include all the growth rings under study. Measurements were made using the system described before (Helinska-Raczkowska, 1990). For each of the annual rings studied, 15 measurements of earlywood and latewood vessel

Table I. Characteristics of the oak trees studied.

Tree characteristics

Tree growth conditions

Dominant Intermediate Suppressed

$\begin{array}{llll}\text { Tree age * (years) } & 76 & 74 & 70 \\ \text { Diameter outside bark }(\mathrm{cm}) & 36 & 23.5 & 18 \\ \text { Tree height }(\mathrm{m}) & 23 & 22 & 16.5 \\ \text { Crown height }(\mathrm{m}) & 12 & 13 & 13 \\ \text { Crown index }{ }^{\star} & 0.5 & 0.6 & 0.8\end{array}$

\footnotetext{
* Number of growth rings on butt-end cross-section; ** ratio of crown length to tree height.
} 
Table II. Characteristics of the oak tree discs studied from $1 / 4$ tree height.

\begin{tabular}{lccc}
$\begin{array}{l}\text { Tree growth conditions } \\
\text { Distance from butt-end }\end{array}$ & $\begin{array}{c}\text { Diameter of disc } \\
(\mathrm{m})\end{array}$ & $\begin{array}{c}\text { Number of growth rings } \\
(\mathrm{nb})\end{array}$ \\
\hline Dominant & & & \\
Intermediate & 5.5 & 27 & 65 \\
Suppressed & 5.5 & 19 & 62 \\
& 4 & 12 & 63
\end{tabular}

lumen diameter (inner diameter) were made. The maximal tangential inner diameter of the first row earlywood vessels in the growth ring and latewood vessels located near the border of growth rings were measured. On the crosssection, the number of earlywood and latewood vessels per unit area, ie their number per $1 \mathrm{~mm}^{2}$ of the transection of earlywood and latewood part of the annual ring, was also determined. However, the number of latewood vessels per unit area was determined at the border of the annual ring.

\section{RESULTS AND DISCUSSION}

Statistical analysis of the measurements indicated that the mean coefficient of variation for earlywood vessel lumen diameter is $17(8 \ldots 32) \%$, while for latewood it is 18 $(10 . .29) \%$. Histograms of the diameters and a comparison of the arithmetical means and modal values suggest that the distribution of vessel lumen diameters is close to normal.

Radial variation of earlywood vessel lumen diameter and the number of earlywood vessels per unit area is shown in figure 1. It follows from these data that the increment of earlywood vessel lumen diameter increases continuously with the increase of cambial age of growth rings up to about $30 \mathrm{yr}$. The vessel lumen diameter remained more or less constant with any further increase of the cambial age of growth rings. Increase in the earlywood vessel lumen diameter in the outerwood was significant compared with that in the pith area; on aver- age it reached $90 \%$. As the age of growth rings increased, the number of earlywood vessels per unit area decreased (fig 1), the variation of this characteristic being the greatest in the area from pith to about the 30 th growth ring. There was a negative correlation between earlywood vessel lumen diameter and their number per unit area (fig 2), which means the greater the earlywood vessel lumen diameters, the lower the number of the earlywood vessels per unit area. For example, for the vessel lumen diameter of $300 \mu \mathrm{m}$, their number per unit area was $5 / \mathrm{mm}^{2}$, while for the diameter of $120 \mu \mathrm{m}$, the number of the vessels per unit area increased to $25 / \mathrm{mm}^{2}$. Such a relationship between the diameter of vessel lumen and their number per unit area can be explained by functional reasons (Bamber and Curtin, 1974; Baas, 1982; Ziemmermann, 1983; Carlquist, 1988). It is also worth mentioning that the diameter of earlywood vessel lumen was negatively correlated with the width of annual rings for a given tree, ie the narrower the annual rings, the greater the diameter of earlywood vessel lumen (fig 3 , for example, for a dominant tree). For latewood vessels, with increasing age of growth rings, an increase in the lumen diameter and in the number of vessels per unit area was observed (table III). However, an increase in the diameter of latewood vessel lumina in the outerwood zone, in comparison with the vessel in the corewood zone was significantly smaller than for earlywood vessels, and on average it amounted to $30 \%$. On the other hand, the number of 


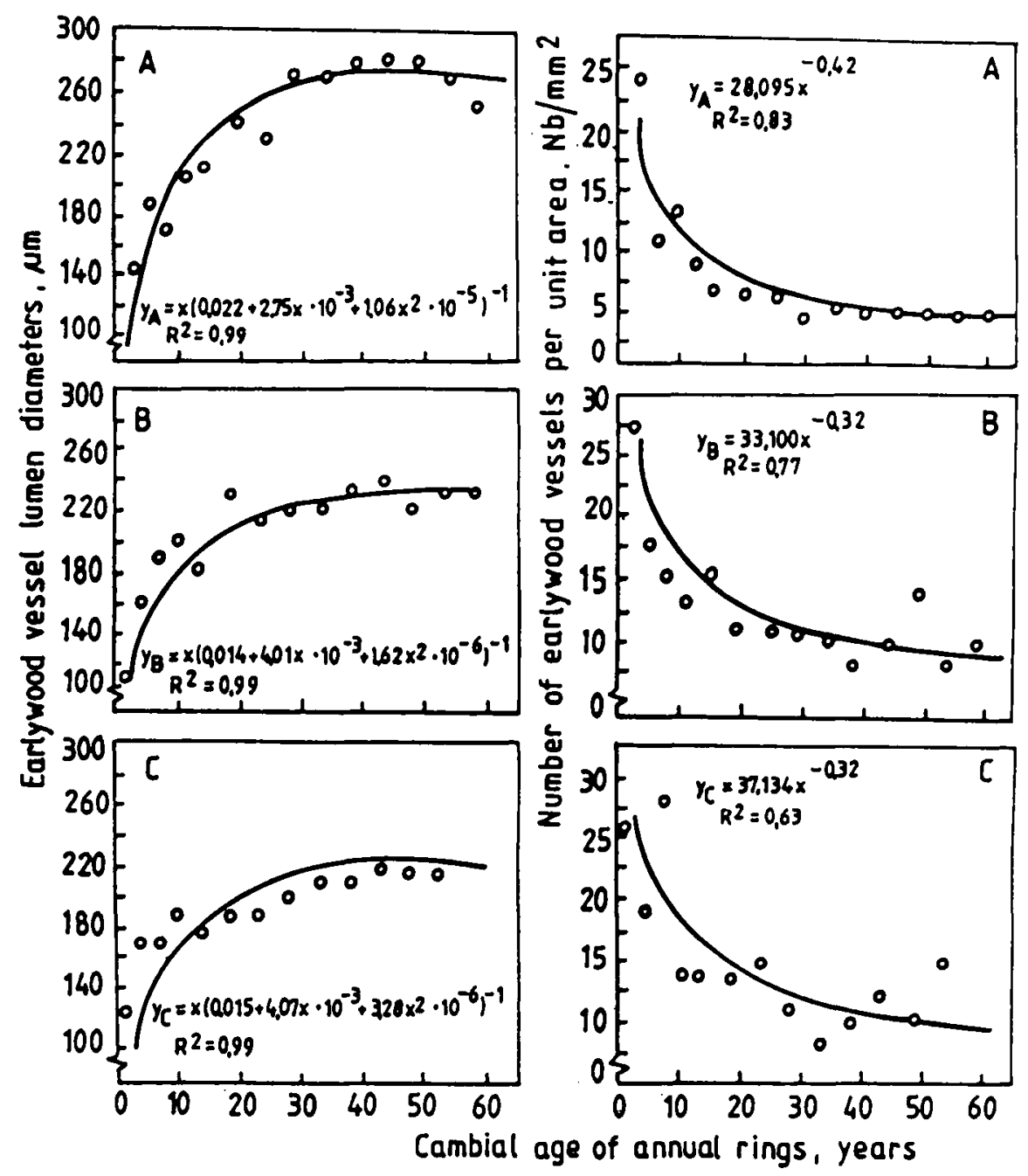

Fig 1. Relationship between the earlywood vessel lumen diameters (left) number of earlywood vessels per unit area (right) and the age of growth rings of the 3 oak trees belonging to dominant $(A)$, intermediate $(B)$, and suppressed $(C)$ trees. Each social status is represented by only one tree, and so no valid conclusion can be inferred about the effect of the social status on vessel characteristics. The equations of the curves are as follows: $A$ (left) $y_{A}=x\left(0.022+2.75 \times \times 10^{-3}+\right.$ $\left.1.06 x^{2} \times 10^{-5}\right)^{-1}, R^{2}=0.99$; (right) $y_{A}=28.095 x^{-0.42}, R^{2}=0.83$; B (left) $y_{B}=x\left(0.014+4.01 \times \times 10^{-3}\right.$ $\left.+1.62 x^{2} \times 10^{-6}\right)^{-1}, R^{2}=0.99$; (right) $y_{\mathrm{B}}=33.100 x^{-0.32}, R^{2}=0.77 ; \mathrm{C}$ (left) $y_{\mathrm{C}}=x(0.015+4.07 x \mathrm{x}$ $\left.10^{-3}+3.28 x^{2} \times 10^{-6}\right)^{-1}, R^{2}=0.99 ;$ (right) $y_{C}=37.134 x^{-0.32}, R^{2}=0.63$.

latewood vessels per unit area tended to increase with the increasing age of the growth ring, even reaching $300 \%$ in the outerwood zone in comparison with the corewood zone.
Radial variation of the number of earlywood and latewood vessels per unit area varied (fig 4). The number of earlywood vessels per unit area decreased as the age of growth rings increased, while that of late- 


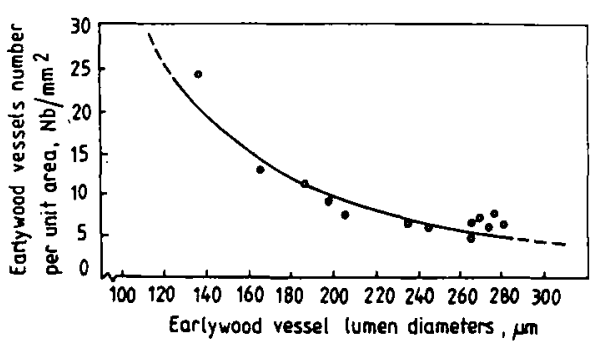

Fig 2. Relationship between number of earlywood vessels per unit area and lumen diameters in the dominant oak tree. The equation of the curve is $y=178142 x^{-1.85}, R^{2}=$ 0.90 .

wood vessels increased. It should be also noted that high variability exists between individual trees for the number of earlywood and latewood vessels per unit area. The same is true for the diameter of earlywood vessel lumina, which varies from $310 \mu \mathrm{m}$ in

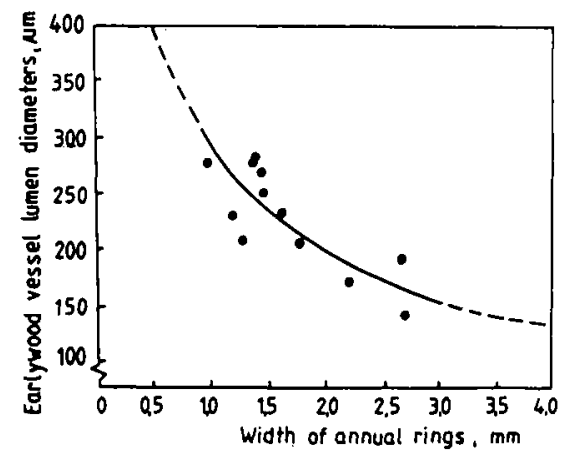

Fig 3. Ring widths and the earlywood lumen diameters in the dominant oak tree. The equation of the curve is $y=293.22 x^{-0.57}, R^{2}=$ 0.65 .

the dominant tree to $220 \mu \mathrm{m}$ in the suppressed tree. Diameters of latewood vessel lumina, on the other hand, exhibit an inter-tree variability but this is lower than for the other above-mentioned characteristics.

Table III. Parameters of the regression equation given by formula $y=x\left(a+b x+c x^{2}\right)^{-1}$ for the relationship between the lumen diameters of latewood vessels $(y, \mu \mathrm{m})$, vessel number per unit area $\left(y, \mathrm{No} / \mathrm{mm}^{2}\right)$ and the age of growth rings of oak trees $(x, y r)$.

Tree growth conditions Regression equation parameters

\begin{tabular}{cccc}
$c$ & \multicolumn{2}{c}{ Regression equation parameters } & $\mathrm{R}^{2}$ \\
\hline 0.095 & $\mathrm{~b}$ & $\mathrm{c}$ & \\
\hline 0.063 & $2.615 \times 10^{-3}$ & $\frac{1.051 \times 10^{-4}}{1.530 \times 10^{-5}}$ & 0.99 \\
\hline$-7.431 \times 10^{-3}$ & 0.052 & $-2.179 \times 10^{-4}$ & 0.99 \\
\hline 0.080 & $2.495 \times 10^{-3}$ & $4.520 \times 10^{-5}$ & 0.93 \\
0.484 & $8.511 \times 10^{-3}$ & $4.524 \times 10^{-4}$ & 0.88 \\
\hline 0.034 & $7.559 \times 10^{-3}$ & $-\frac{2.335 \times 10^{-5}}{2}$ & 0.87
\end{tabular}




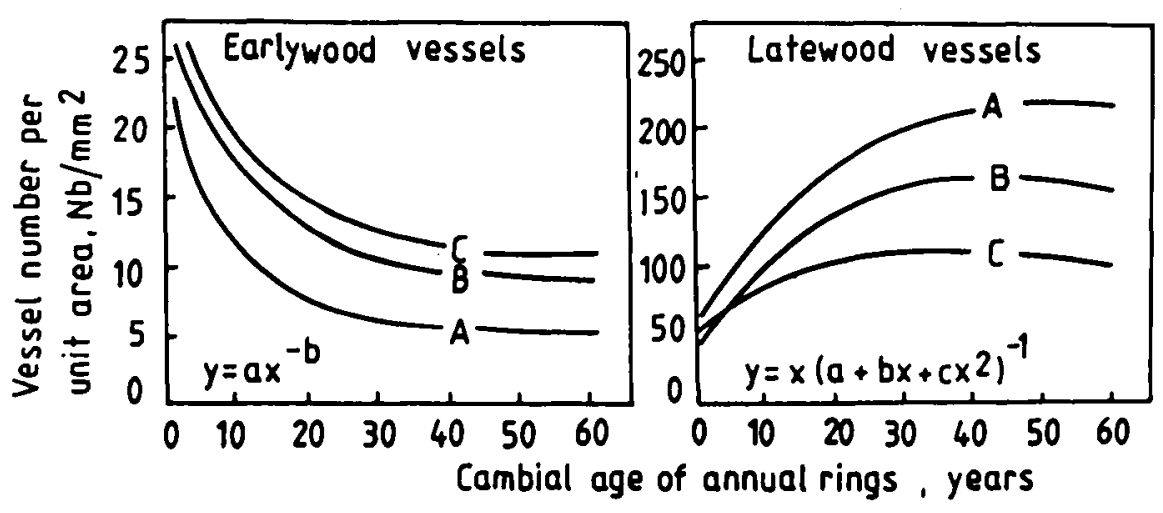

Fig 4. Between-tree variability in an even-aged stand on number per unit area of the earlywood (left) and latewood (right) vessels; A: dominant; B: intermediate; C: suppressed tree. Each social status is represented by only one tree and so no valid conclusion can be inferred about the effect of the social status on vessel characteristics. The equations of the curves are as follows: earlywood: $y$ $=a x^{-b}$; latewood $y=x\left(a+b x+c x^{2}\right)^{-1}$.

The absolute values of the vessel lumen diameter measured were similar to those reported in the literature (Wagenführ and Scheiber, 1974; Wagenführ, 1984; Wagenführ et al, 1989). As regards the number of latewood vessels per unit area in the mature wood, the values obtained are closest to those collected by Vichrov (1954).

The curves of radial varation of earlywood vessel lumen diameter or number per unit area of vessels may be used as an indicator of the border between the juvenile (corewood) and the mature wood (outerwood). The zone of juvenile wood may be assumed to comprise growth rings from pith to those that have either a constant diameter of earlywood vessel lumen or a constant number per unit area. In other words, the number of years taken to reach a more or less constant earlywood lumen diameter or its number per unit area may be used as a junction between the juvenile and the mature wood in oak. Due to the value of the determination coefficient $R^{2}$, the diameter of the vessel lumen is preferable as the indicator. In the case considered here, the transition period of juvenile wood into mature wood would be about $30 \mathrm{yr}$ on visual estimation. The same limit can be (visually) accepted for the 3 trees considered here. It is worth mentioning that the juvenile period of oak development, determined on the basis of changes in earlywood vessel lumen diameter, overlaps the zone of juvenile wood determined on the basis of radial variation in fibre length (Helińska-Raczkowska and Fabisiak, 1991). Moreover, it should be noted that the juvenile period of oak development, determined on the basis of radial variation in wood anatomical elements, corresponds to the juvenile period of tree development established on the basis of the number of years a tree needs to achieve reproduction capabilities, which for $Q$ robur usually takes from 25 to $30 \mathrm{yr}$ (Wareing and Philips, 1985).

Juvenile oak wood was characterized by wider growth rings than mature wood, a higher percentage of latewood, and a higher wood density (dry weight, green volume basis) by about $100 \mathrm{~kg} / \mathrm{m}^{3}$. Average density differentiation of examined oak wood is given in table IV. However, an attempt to use these parameters to differ- 
Table IV. Average density differentiation of examined oak wood.

Tree growth conditions

Corewood (<30th ring) Outerwood (> 30th ring)

Difference

\begin{tabular}{llrr}
\hline Dominant tree & 590 & 490 & 100 \\
Intermediate tree & 620 & 550 & 70 \\
Suppressed tree & 600 & 500 & 100 \\
\hline
\end{tabular}

entiate between juvenile and mature wood failed.

Generally, the results of our studies are in agreement with the basic laws of ecological and functional anatomy, by which we mean the broadly understood influence of climatic, biotic, and edaphic factors on the variations in wood structure. According to these laws, deteriorated conditions of tree growth may result in a decrease in the diameter of earlywood vessels and increase their number per unit area (Carlquist, 1988; Van den Over et al, 1981; Baas, 1982). The comparison between the 3 trees taken into consideration here ( 1 dominant, 1 intermediate, 1 suppressed tree) seems to be in accordance with these bibliographic results but our sampling is not complete enough to confirm this point seriously. However knowledge of the laws mentioned above with reference to hardwoods is limited (Denne and Dood, 1981), which has also been evidenced in this paper. Due to the scarcity of experimental material, this study should be considered as an introductory. It seems necessary therefore to extend these studies to other species from the Quercus genus and to other genera from the group of ringporous wood (eg, Fraxinus, UImus and Robinia).

\section{CONCLUSIONS}

Radial variation of the diameter of earlywood vessels in oak and their number per unit area is generally related to the age from the pith in the juvenile wood (corewood). With increasing age of growth rings, the diameter of earlywood and latewood vessel lumina and the number of latewood vessels per unit area increases, while the number of earlywood vessels per unit area decreases. The zone of juvenile wood determined from the curves of radial variation in earlywood vessel lumen diameter consists of approximately 30 growth rings. For the same age from the pith, a very significant tree effect appears for the diameter of vessel lumen and the number of vessels per unit area.

\section{REFERENCES}

Baas P (1982) Systematic, phylogenetic, and ecological wood anatomy - history and perspectives. In: New Perspectives in Wood Anatomy ( $P$ Baas, ed) Martinus Nijhoff, Dr W Junk Publ, Hague, 45

Bamber RK, Curtin RA (1974) Some properties of wood Blackbutt trees of two ages. Austr For 36, 226-234

Carlquist S (1988) Comparative Wood Anatomy. Springer Series in Wood Science, SpringerVerlag, Berlin, 44-46, 54

Denne MP, Dood RS (1981) The environmental control of xylem differentiation. In: Xylem Cell Development (JR Barnett, ed) Castle House Publ Ltd, Tunbridge Wells, Kent, 236-253

Gasson P (1985) Automatic measurements of vessel lumen area and diameter with particular reference to pedunculate oak and common beech. IAWA Bu/lns 6, 219-237 
Helińska-Raczkowska L (1990) Wymiary i rozstaw promieni drzewnych $w$ drewnie debu (Quercus petraea Liebl) w zaleźnosći od klasy biosocjalnej drzew. Folia For Polon S B 21. 97-111

Helińska-Raczkowska L, Fabisiak E (1991) Radial variation and growth rate in the length of the axial elements of sessile oak wood. IAWA Bull n s 12, 257-262

Maeglin RR (1976) Natural variation of tissue proportion and vessel and fiber in mature northern red oak. Silvae Genet 25, 122-126

Nepveu G (1981) Prédiction juvénile de la qualité du bois de Hêtre. Ann Sci For 38, 425-448

Nepveu G (1984a) Déterminisme génetypique de la structure anatomique du bois chez Quercus robur. Silvae Genet 33, 91-95

Nepveu G (1984b) Contrôle héréditaire de la densité et de la rétractabilité du bois de trois espèces de chêne (Quercus petraea, Quercus robur et Quercus rubra). Silva Genet 33 , 110-115

Nepveu G (1990) Les facteurs influençant la qualité du bois de chêne (chêne rouvere et chêne pédonculé). Rev For Fr 42, 128-133

Over van den L, Baas P, Zandee M (1981) Comparative wood anatomy of Symplocos and latitude of provenance. IAWA Bull $n$ s 2, 3-24
Petric B, Šcukanec V (1980) Neke strukturne karakteristike juvenilnog i zrelog drva hrasta luznjaka (Quercus robur L). Drvna Ind 31, 8186

Trotter PC (1986) Biotechnology and the economic productivity of commercial forests. Tappi $J 69,22-28$

Vichrov VE (1954) Strojenije i fiziko-mechaniceskije svojstva dreviesiny duba. Izd AN SSSR, Moskva, 130, 153

Wagenführ R (1984) Anatomie des Holzes. VEB Fachbuchverlag, Leipzig, 96

Wagenführ $\mathrm{R}$, Scheiber $C$ (1974) Holzatlas. VEB Fachbuchverlag, Leipzig, 342

Wagenführ R, Nake R, Weiss B (1989) Vergleichende Betrachtungen einheimischer und importierter Eichenarten unter Beachtung ihres Einsatzes in der Furnierindustrie. Holztechnologie 30, 134-136

Wareing PF, Philips IDJ (1985) Wzrost i róznicowanie sie roślin. Panstw Wyd Naukowe, Warszawa, 497

Ziemmermann MH (1983) Xylem Structure and the Ascent of Sap. Springer-Verlag, Berlin, 15,16

Zobel BJ, van Buijtenen JP (1989) Wood Variation. Its Causes and Control. Springer Series in Wood Science, Springer-Verlag, Berlin, 94 